\title{
Polarographic Methods for Determination of Ascorbic Acid in Pharmacetical Preparations
}

\author{
Swaroopa Rani N. Gupta, Member, APCBEES
}

\begin{abstract}
Ascorbic acid is determined polarographically present in various types of medicinal samples by internal standard addition method. Potassium hydrogen phthalate buffer ( $\mathrm{pH}$ 4.0) containing $0.25 \%$ oxalic acid and $0.008 \%$ gelatin solution used as supporting electrolytes and maxima suppressor. Presence of colouring matters does not interfere, and sample handling and solution preparation for analysis can be carried out sufficiently fast to prevent appreciable oxidation. Polarographic determination of ascorbic acid can be carried out even in presence of comparable amounts of other ingredients such as Vitamins A, B, C, D, and E.

Results of estimation of ascorbic acid present in different multivitamin medicinal samples by internal standard addition method obtained are in good agreement with the quoted values. The method is precise as indicated by low values of standard deviation.

Comparative study of ascorbic acid estimation by polarographic internal standard addition method with respect to their manufacturing company was also done.
\end{abstract}

Index Terms-Ascorbic acid, internal standard addition method, medicinal samples, polarographic determination.

\section{INTRODUCTION}

Additional research is discovering that vitamin $\mathrm{C}$ can be helpful in preventing asthma [1]. Protecting against cancer, [2] and supporting healthy blood sugar levels in diabetics [3]. While often taken for granted, vitamin $\mathrm{C}$ is a critical supplement in our program to improve cardiac health and avoid degenerative diseases.

A method is described for the polarographic determination of total ascorbic acid. It is based on reduction of dehydroascorbic acid to ascorbic acid with homocysteine, treatment with $\mathrm{N}$-ethylmaleimide to remove the interference of homocysteine and subsequent polarographic determination of the total amount of ascorbic acid present. This method has been applied to a variety of food products [4].

A method for the concurrent polarographic determination of ascorbic acid (99.98 \%) (I), folic acid (88.9, p-aminobenzoylglutaminic acid 4.35, and moisture $6.51 \%$ ) (II) andriboflavine (III) was decribed using a borate-phosphate buffer solution $(\mathrm{pH}$ 6.8) free of dissolved O.

The half - wave potentials $\left(\mathrm{E}_{1 / 2}\right)$ for $0.5 \% \mathrm{I}, 0.01 \% \mathrm{II}$, and $0.02 \%$ III were $0.01,0.7$ and $0.4 \mathrm{~V}$ respectively. The method was suitable for both qualitative and quantitative determinations either in mono- or polyvitamin mixtures. The

Manscript received January 23, 2014; revised July 1, 2014.

Swaroopa Rani N. Gupta is with the Department of Chemistry, Brijlal Biyani Science College Amravati, Maharashtra, India (e-mail: swargupta@yahoo.com). error did not exceed $1 \%$ for I, $2 \%$ for II and $1.5 \%$ for III. The speed of the analysis was twice as fast as previous determinations taking a maximum of 70 minutes [5].

Ascorbic acid was determined in a variety of foods by extracting $20 \mathrm{gm}$ with $2 \%$ oxalic acid, filtering, diluting the filtrate with $\mathrm{H}_{2} \mathrm{O}$ and $4 \mathrm{M}$ acetate buffer $(\mathrm{pH}$ 4.64) and measuring with a $\mathrm{Hg}$ drop electrode and a $\mathrm{Ag} / \mathrm{AgCl} / \mathrm{KCl}$ reference electrode. The half-wave potential was $0.06 \mathrm{~V}$. Recoveries were 96-103\% [6].

A 2-5 gm spice sample was extracted with $50 \mathrm{ml} 1 \%$ oxalic acid for $20 \mathrm{~min}$ and centrifuged. After bubbling with $\mathrm{N}$, $1-3 \mathrm{ml}$ of the supernatant was mixed with $25 \mathrm{ml}$ acetate buffer, $\mathrm{pH}$ 4.6, and the ascorbic acid was determined by polarography. Savory, red pepper, thyme, onion powder, tarragon, garlic, leek, parsley, and chives obtained 86.8, 30.6 - 54.3, 32.9, 1.4, 13.5, 7.2, 45.9, 33.9, and $48.6 \mathrm{mg} \%$ ascorbic acid respectively [7].

Vitamin $\mathrm{C}$ was determined by using an excess of a crude extract of ascorbate oxidase from tropical pumpkin and polarographic detection of $\mathrm{O}$ consumtion with a Clark electrode, and the method was used for determining the vitamin $\mathrm{C}$ content of diluted lemon juice. The vitamin $\mathrm{C}$ content of lemon juice was $67.4 \%$, whereas a value of 125 $\mathrm{mg} \%$ was obtained by using the 2,6 dichlorophenolindophenol method of C. J. Farmer and A. F. Abt (1936). The higher value obtained by the colorimetric method is probably due to interferences which lead to overestimation of vitamin C content [8].

A simple, rapid and accurate method for the simultaneous determination of ascorbic acid, caffeine and paracetamol in drug formulations has been developed. Peak currents were measured with a glassy carbon electrode at $+0.350,+0.618$ and $+1.425 \mathrm{~V}$ versus a saturated calomel electrode for ascorbic acid, paracetamol and caffeine, respectively. Perchloric acid $(0.1 \mathrm{M})$-methanol $(1+1)$ was used both as a solvent and supporting electrolyte. The optimum modulation amplitude, pulse repeat time and scan rate of the polarographic analyser were found to be $50 \mathrm{mV}, 0.5 \mathrm{~s}$ and 5 $\mathrm{mV} \mathrm{s}^{-1}$, respectively and the linear calibration ranges for ascorbic acid, caffeine and paracetamol were $0-35,0-50$, and $0-55 \mu \mathrm{g} \mathrm{ml}^{-1}$, respectively. The relative standard deviations for $9.30 \mu \mathrm{g} \mathrm{ml}^{-1}$ of ascorbic acid, $8.50 \mu \mathrm{g} \mathrm{ml}^{-1}$ of caffeine and $7.30 \mu \mathrm{g} \mathrm{ml}^{-1}$ of paracetamol were $1.3,2.5$ and $0.7 \%$, respectively. Results are reported for several commercially available drugs [9].

A polarographic method is described for the simultaneous determination of ascorbic acid and dipyrone in dosage forms. The method is based on the anodic polarographic waves produced by both compounds in Walpole acetate buffer $(\mathrm{pH}$ 3.6). The separation of the two waves $(>0.65 \mathrm{~V})$ is sufficient to allow accurate measurements. The proposed method was successfully applied to the analysis of commercially 
available ampules, and the results obtained were of satisfactory accuracy and precision [10].

A sensitive and selective method is described for the determination of ascorbic acid by stripping voltammetry on a glassy carbon electrode. It involves formation of ferroin when ascorbic acid reacts with a mixture of iron (III) and 1,10-phenanthroline. Ferroin is adsorbed on the glassy carbon electrode followed by stripping voltammetric measurement in the cathodic direction. A linear concentration range is obtained from $2.0 \times 10^{-7}-2.2 \times$ $10^{-6} \mathrm{~g} / \mathrm{ml}$ for an accumulation period of $30 \mathrm{~s}$. The method was successfully employed for the determination of ascorbic acid in fruit and vegetable juices. Comparison of the results obtained for the juices demonstrated reasonable agreement with those obtained by a spectrophotometric method [11].

The ascorbic acid content of fruit and vegetables was determined by normal polarography. It was found that oxalic acid and EDTA protected the vitamin during the sample preparation procedure but oxalic acid was preferred to be used for polarographic analysis. Citrate buffer was used as the supporting electrolyte since it was already present in fruit and vegetables and resisted the change in $\mathrm{pH}$ upon the addition of the fruit extract. The most suitable $\mathrm{pH}$ of the supporting electrolyte was determined to be 4.5 . A procedure is suggested for the determination of ascorbic acid in fruit and vegetables. The standard deviation for the method based upon the pooled precision data was found to be 1.0 for tomatoes and 3.1 for oranges [12].

Interactions between lead and ascorbic acid were investigated by polarography and voltammetry. The following techniques were applied: sampled polarography, differential pulse anodic stripping voltammetry, and square-wave voltammetry. Measurements were performed in perchlorate aqueous solutions under physiological ionic strength $(0.15 \mathrm{~mol} \mathrm{dm}(-3))$. Electrochemical reaction of the lead(II) ascorbate complex was studied in various electrolyte compositions to find the optimal measurement conditions for determination of the corresponding stability constants $\left(\left[\mathrm{Pb}^{2+}\right]\right.$ $=4 \times 10(-7) \mathrm{mol} \mathrm{dm}(-3), \mathrm{pH}=5.5$; total concentration of ascorbic acid between 10(-5) and 10(-1) mol $\mathrm{dm}(-3))$. Determination of stability constants of labile lead(II) ascorbate complexes was based on the DeFord-Hume methodology, and they were calculated from the dependence of the shift of $\mathrm{Pb}$-II peak potential on the free ascorbate ion concentration. The computed stability constants were: $\log$ $\operatorname{beta}(1)=9.3+/-0.2$ and $\log \operatorname{beta}(2)=18.0+/-0.1[13]$.

L-ascorbic acid was determined in aqueous media by linear-scan voltammetry on a gold electrode; ranging between $(1-175 \mu \mathrm{g} / \mathrm{mL})$. In biologic samples, for elimination of uric acid or some sugars and effects, a significant interference of copper ions whose presence reduces the height of the L-ascorbic acid oxidation peak was used [14].

A differential pulse polarographic (DPP) method has been developed for the determination of ascorbic acid (AA) and dehydroascorbic acid (DHA), the two main forms of Vitamin C. The method consists of the DPP analysis of a quinoxaline obtained by the derivatization of DHA with o-phenylenediamine. Results using the proposed method correlated well with those obtained by two reference methodologies: the common iodometric method and a published chromatographic methodology. It was also used in the study of Vitamin $\mathrm{C}$ degradation in fruit juices, showing that it involves an initial oxidation of AA to DHA, followed by hydrolytic degradation of the latter [15].

DC polarographic method was developed for estimation of ascorbic acid (vitamin C) in pharmaceutical formulations. Parameters like concentration of supporting electrolyte, maximum suppressor, $\mathrm{pH}$, mercury flow rate and drop time were optimized. Under optimum conditions, a well-defined sigmoid curve was observed with diffusion current proportional to the concentration of ascorbic acid. Analytical quality control was carried out with determination of relative mean deviation, standard deviation and regression studies. The method was found to be simple, rapid and reproducible. The optimized method was applied to various pharmaceutical formulations available in local market. The results obtained were found to be in agreement with the certified values [16].

\section{MEthodology}

All chemicals were of A. R. Medicinal samples were collected from local market of different make. D.C. Toshniwal manual polarograph with a digital display to read current and voltage was used to record the polarograms. Dropping Mercury Electrode (D.M.E.) was used as anodic current indicator while Saturated Calomel Electrode (S.C.E.) was used as cathode. Saturated KCI salt bridge was used to connect them. The mercury drop rate was maintained at around 20 drops per minute. $50 \mathrm{ml}$ total volume was maintained for each measurement.

Internal standard addition method was developed for the determination of ascorbic acid from medicinal samples. For the analysis of a solution used as syrup or drops, to an accurately measured volume equivalent to about $100 \mathrm{mg}$ of ascorbic acid, sufficient potassium hydrogen phthalate buffer ( $\mathrm{pH} 4$ ) containing $0.25 \%$ oxalic acid was added to produce $100 \mathrm{ml}$. Five systems were prepared by taking an aliquot of this solution equivalent to about $5 \mathrm{mg}$ of ascorbic acid, $1 \mathrm{ml}$ $0.4 \%(\mathrm{pH}=4)$ gelatin solution and measured amount of a standard solution of ascorbic acid $(\mathrm{pH}=4)$ containing $0,1.76$, $3.52,5.28$ and $7.04 \mathrm{mg}$ of it. Each system was diluted to 50 $\mathrm{ml}$ with buffer solution $(\mathrm{pH}=4)$ and polarogram was recorded on Toshniwal Manual Polarograph as described earlier. The resulting diffusion currents were plotted against the concentration of the standard solutions that were added to the unknown. The extrapolated line intersecting the response axis indicated the concentration of the ascorbic acid in the unknown sample. The values were also calculated using the standard addition equation. The determination of ascorbic acid in tablet or capsule is carried out by dissolving accurately weighed powered quantity of the single table/capsule, containing about $100 \mathrm{mg}$ of ascorbic acid, as completely as possible in $100 \mathrm{ml}$ of the buffer $\mathrm{pH} 4.0$ and clear supernatant liquid was taken for further analysis as described in case of syrup or drops.

\section{OBSERVATIONS}

Anodic waves for application of the method of internal standard addition in the determination of ascorbic acid in different medicinal samples are is shown in Fig. 1 (A to R). Table I indicates the results of estimation of ascorbic acid present in different multivitamin medicinal samples by 
internal standard addition method. The results thus obtained precise as indicated by the low values of standard deviation. are in good agreement with the quoted values. The method is

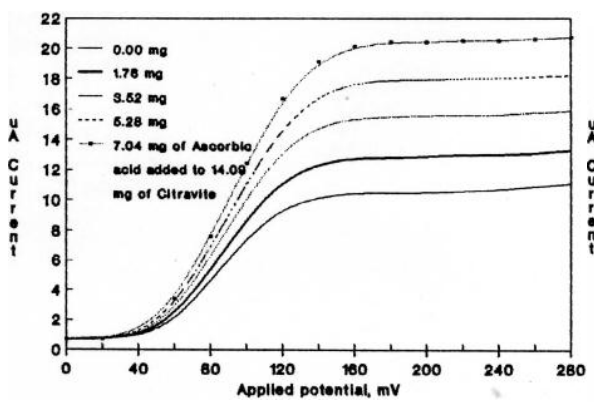

(A)

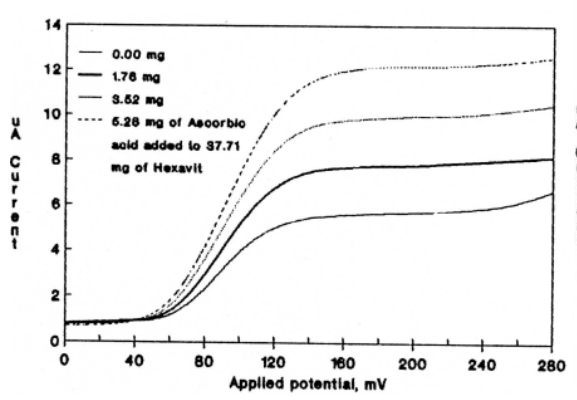

(D)

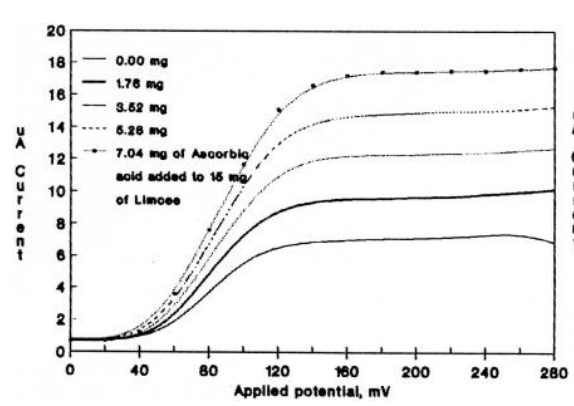

(G)

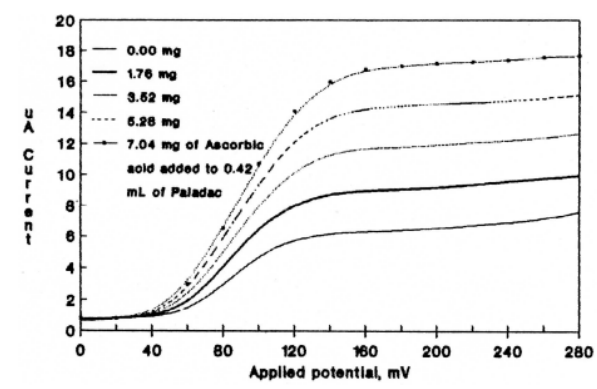

(J)

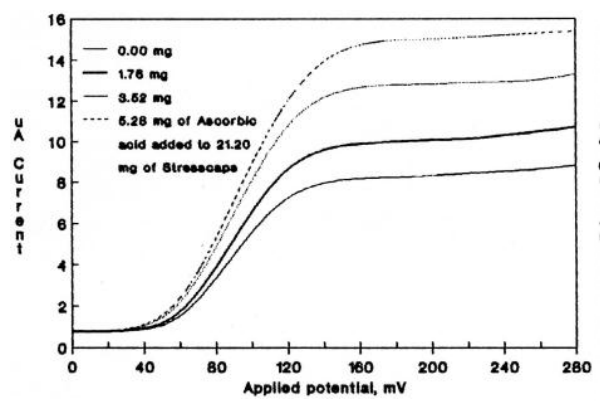

(M)

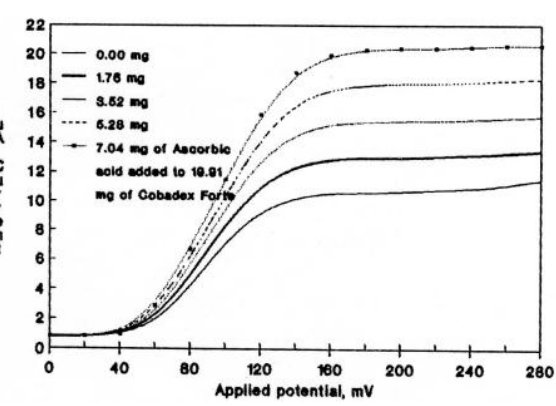

(B)

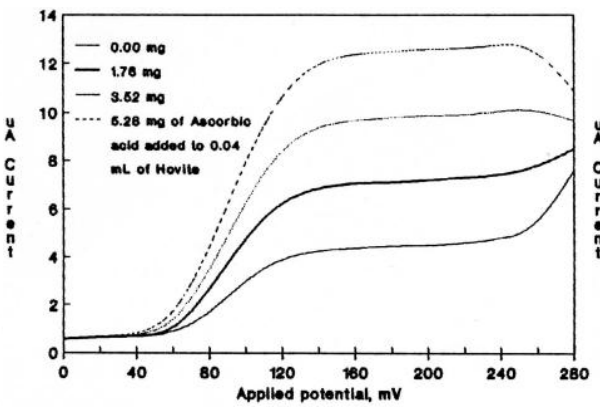

(E)

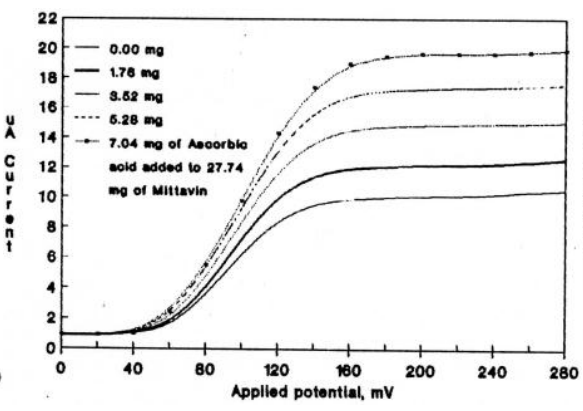

$(\mathrm{H})$

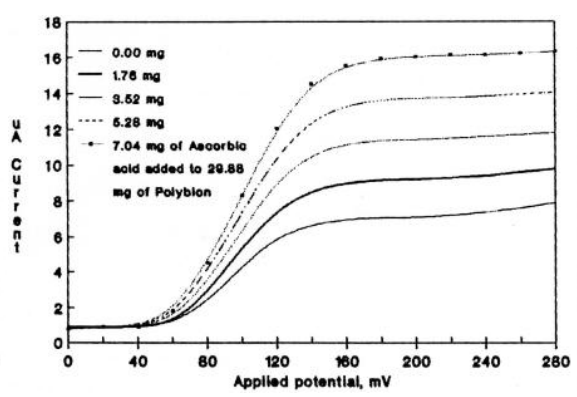

(K)

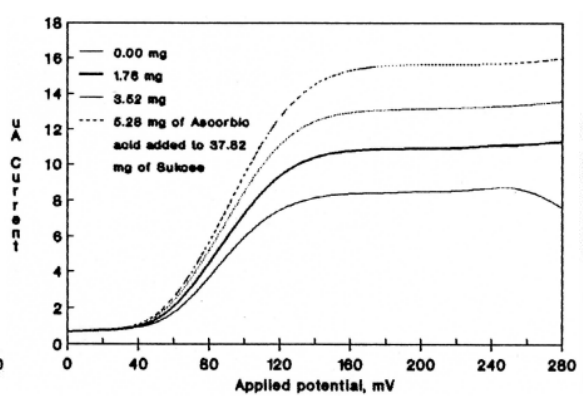

$(\mathrm{N})$

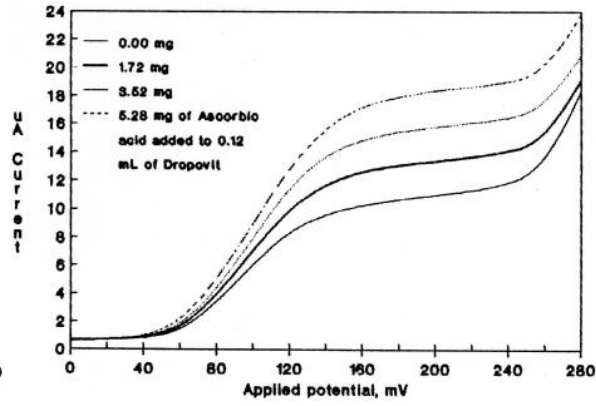

(C)

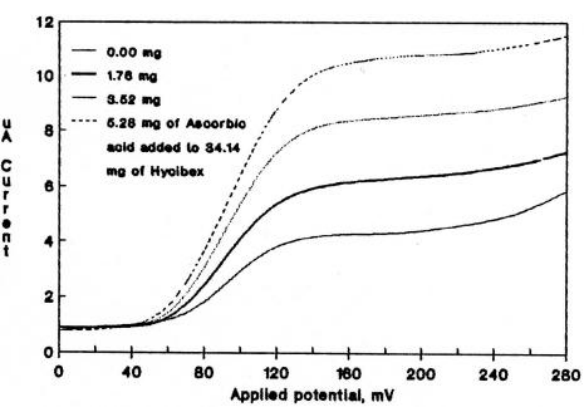

(F)

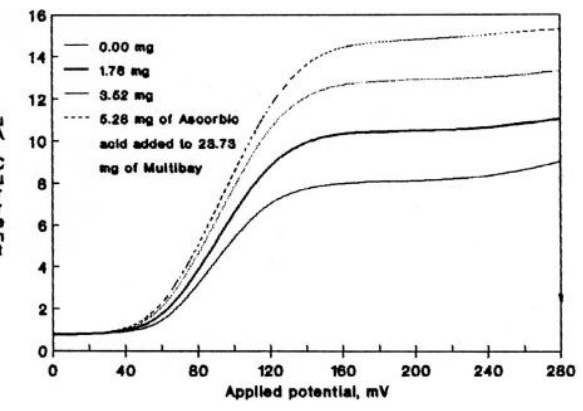

(I)

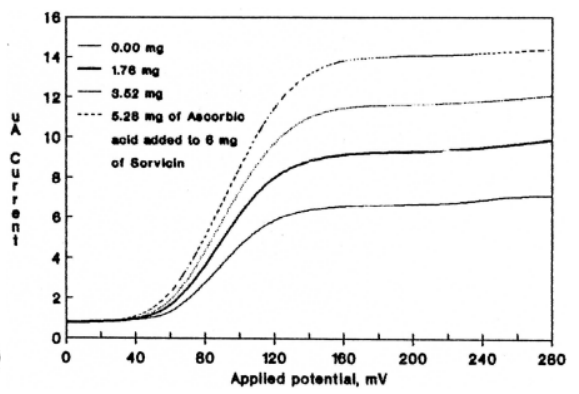

(L)

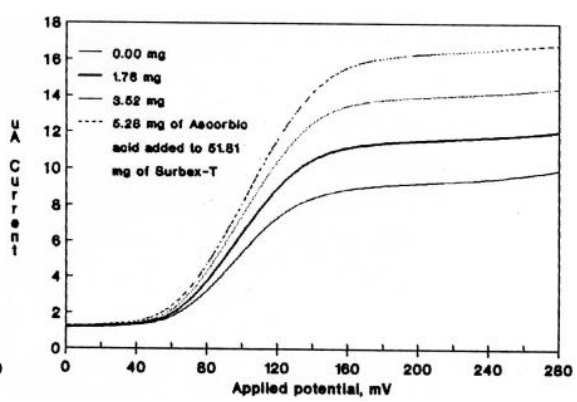

(O) 


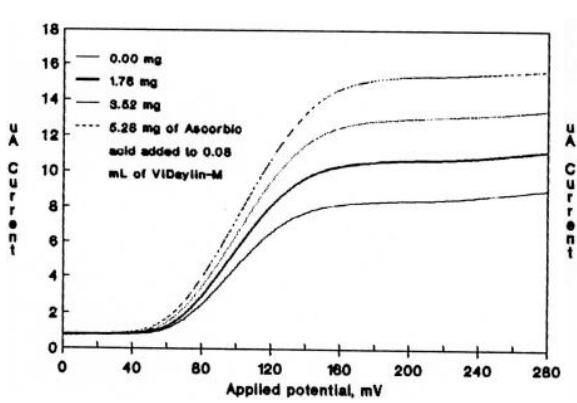

(P)

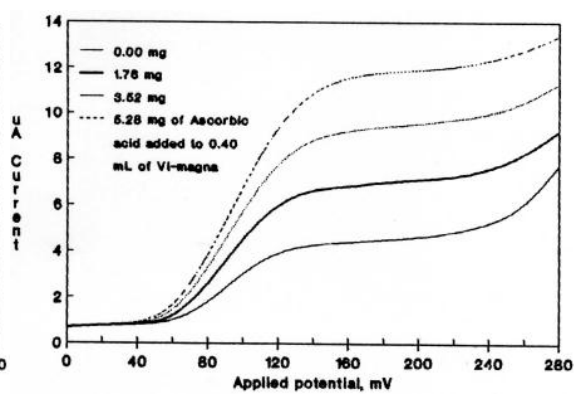

(Q)

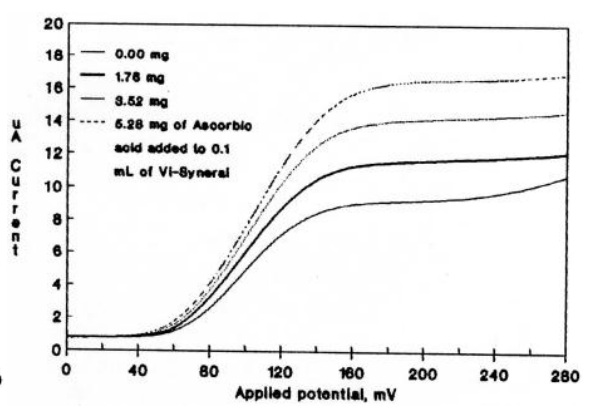

(R)

Fig. 1. Polarographic determination of ascorbic acid in multivitamin medicinal samples by internal standard addition method (A) to (R).

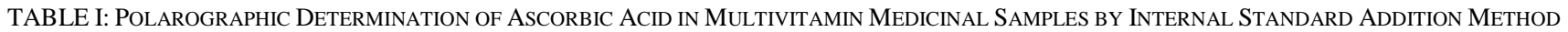

\begin{tabular}{|c|c|c|c|c|}
\hline \multirow[t]{2}{*}{ Multivitamin Medicinal Sample } & \multirow{2}{*}{$\begin{array}{l}\text { Wt of Tablet/ Capsule } \\
\text { material, } g\end{array}$} & \multirow{2}{*}{$\begin{array}{l}\text { Wt of empty } \\
\text { Capsule, g }\end{array}$} & \multicolumn{2}{|c|}{$\begin{array}{c}\text { Amount of Ascorbic acid per Tablet / } \\
\text { Capsule, } g\end{array}$} \\
\hline & & & Quoted & Found \\
\hline Citravite (Pharmed) Tablet & 1.0080 & - & 0.5 & $0.485 \pm 0.005$ \\
\hline Cobadex Forte (Glindia) Capsule & 0.4105 & 0.0762 & 0.15 & $0.150 \pm 0.004$ \\
\hline Dropovit (Manners) Drops & - & - & $0.04 / 0.6 \mathrm{ml}$ & $0.0399 \pm 0.0003$ \\
\hline Haxavit (IDPL) Tablet & 0.4357 & - & 0.05 & $0.0471 \pm 0.0004$ \\
\hline Hovite (Raptakos) Drops & - & - & $0.08 / \mathrm{ml}$ & $0.071 \pm 0.003$ \\
\hline Hycibex (Pharmed) Capsule & 0.4183 & 0.0929 & 0.075 & $0.036 \pm 0.001$ \\
\hline Limcee (Sarabhai) Tablet & 1.4852 & - & 0.5 & $0.4213 \pm 0.0000$ \\
\hline Mittavin (Boehringer-k) Capsule & 0.5813 & 0.0797 & 0.15 & $0.144 \pm 0.006$ \\
\hline Multibay (Bayer) Capsule & 0.4061 & 0.0777 & 0.1 & $0.096 \pm 0.003$ \\
\hline Paladac (Parke-Davis) Aqueous Prep. & - & - & $0.0625 / 5 \mathrm{ml}$ & $0.0436 \pm 0.0004$ \\
\hline Polibion (Merck) Tablet & 0.7503 & - & 0.15 & $0.129 \pm 0.003$ \\
\hline Sorvicin (East India) Tablet & 0.6709 & - & 0.5 & $0.453 \pm 0.007$ \\
\hline Stresscaps (Cyanamid) Capsule & 0.4457 & 0.0761 & 0.15 & $0.14 \pm 0.02$ \\
\hline Sukcee (IDPL) Tablet & 1.0881 & - & 0.5 & $0.4863 \pm 0.0000$ \\
\hline Surbex $-\mathrm{T}$ (Abbott)Tablet & 1.0762 & - & 0.15 & $0.130 \pm 0.004$ \\
\hline ViDaylin -M (Abbott) Drops & - & - & $0.05 / 0.6 \mathrm{ml}$ & $0.0412 \pm 0.0003$ \\
\hline Vi-magna (Cyanamid) Syrup & - & - & $0.05 / 5 \mathrm{ml}$ & $0.0367 \pm 0.0005$ \\
\hline Vi-Syneral (USV) Drops & - & - & $0.04 / 0.6 \mathrm{ml}$ & $0.361 \quad 0.0004$ \\
\hline
\end{tabular}

\section{RESULTS AND DISCUSSION}

Ascorbic acid (vitamin C) is easily oxidized to dehydroascorbic acid. This oxidation can be achieved not only by chemical oxidizing agents, but also electrochemically at the surface of the dropping mercury electrode. The oxidation takes place at rather positive potentials and results in negative currents are recorded. On polarographic curves, the oxidation of ascorbic acid thus results in anodic waves.

\section{Polagraphic Determination of Ascorbic Acid}

Ascorbic acid is a strong reducing agent at higher $\mathrm{pH}$ values reduces even atmospheric oxygen. Therefore, low $\mathrm{pH}$ values are preferred for preparation of standard ascorbic acid solution. A potassium hydrogen phthalate buffer ( $\mathrm{pH} 4.0$ ) containing $0.25 \%$ oxalic acid has proved useful for the preparation of supporting electrolytes used in determination of ascorbic acid in medicinal samples and other polarographic experiments. In the analyses of aqueous preparations such as syrup or vitamin $\mathrm{C}$ drops the sample is diluted with this buffer, while in case of Tablet or capsule, vitamin $\mathrm{C}$ is extracted with the same buffer. The absence of atmospheric oxygen gives good anodic waves but the presence of oxygen does not affect the wave.

Ascorbic acid (Vitamin C) is determined polarographically present in various types of medicinal samples by measuring the anodic waves that correspond to the oxidation of the enediol system by internal standard addition method. The presence of colouring matters does not interfere, and the sample handling and solution preparation for analysis can be carried out sufficiently fast to prevent appreciable oxidation. Furtheremore, the polarographic determination of ascorbic acid can be carried out even in the presence of comparable amounts of other ingredients such as Vitamins A, B, C, D, and $\mathrm{E}$.

Whereas in the commonly used titrimetic methods these may also be partly titrated. The handling of the material for analysis depends upon whether the material is an aqueous preparation, tablet or capsule and whether the ascorbic acid content is high or low.

For the analysis of a solution used as syrup or drop, sufficient buffer is to be added so that the final volume 
contains about $0.1 \mathrm{~g}$ of ascorbic acid in $100 \mathrm{ml}$. The $\mathrm{i}_{\mathrm{d}}$ is computed from recorded anodic wave and the graphs are plotted $i_{d}$ as a function of concentration of the standard solutions that are added to the unknown. The values of unknown quantities of ascorbic acid are computed for internal standard addition method. The values are also calculated using the standard addition equation. The same method is followed in case of tablet/capsule material. Fig. 2 (A to $C$ ) are the graphic representation of the internal standard addition method of evaluation for different medicinal samples.

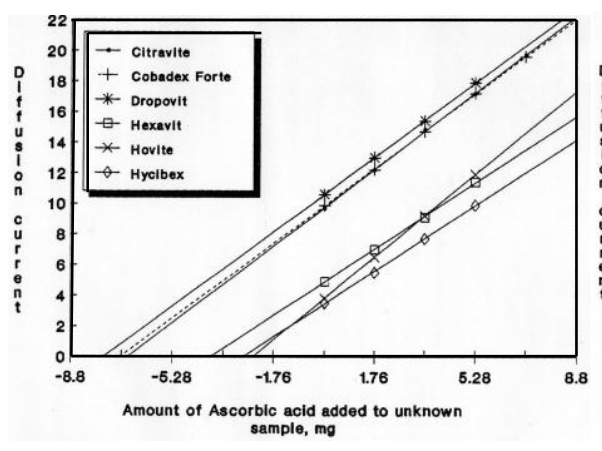

(A)

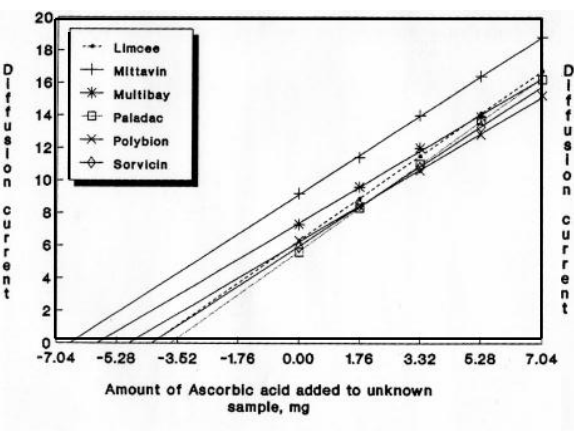

(B)

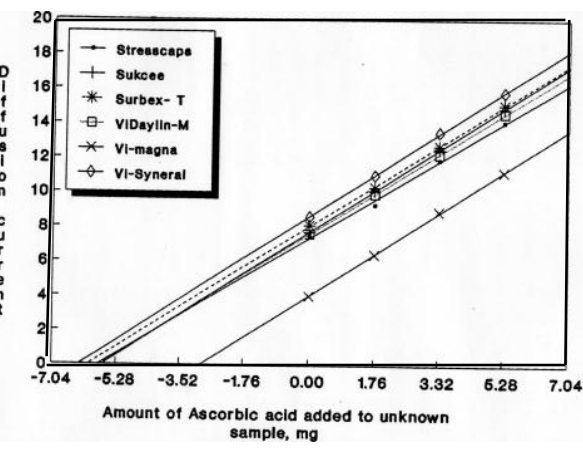

(C)

Fig. 2. Plot of diffusion current as function of amount of ascorbic acid added to multivitamin medicinal sample.

Well defined C-V curves are obtained between 0-280 mV. In case of Dropovit, sharp increase in current at $220 \mathrm{mV}$ is observed may be due to the dissolution of mercury from the dropping electrode (anode). Hovite, at $260 \mathrm{mV}$ for lower concentration of vitamin $\mathrm{C}$ mercury dissolution predominates than that of adsorption of mercury compound at the electrode-solution interface thus sharp increase in current is noted but for higher concentration of vitamin $\mathrm{C}$ reverse picture is pointed out from $260-280 \mathrm{mV}$ range. It is observed that the amount of ascorbic acid found are in good agreement with the quoted values (Table I) except in a very few cases where less recovery is calculated may be due to loss on storage. The comparative study for estimation of ascorbic acid by polarographic internal standard addition method with respect to their manufacturing company (Table II) on an average reveals that vitamin $\mathrm{C}$ sample thus analyzed and obtained from Bayer, Boehringer-knoll, Cyanamid, East India, Glindia, IDPL, Manners, Pharmed and U.S.V. presents better result than that obtained from Abbott, Merck, Parke-Davis, Raptakos, Sarabhai. Lower recovery may be due to interference in the anodic reaction of ascorbic acid by other constituent present in the medicine.

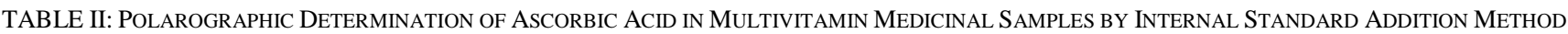

\begin{tabular}{|c|c|c|c|c|}
\hline \multirow{2}{*}{$\begin{array}{c}\text { Manufacturing } \\
\text { Company }\end{array}$} & \multirow{2}{*}{ Medicinal Sample } & \multicolumn{2}{|c|}{ Amount of Ascorbic Acid per Tabler/Capsule, $g$} & \multirow{2}{*}{ Remarks } \\
\hline & & Quoted & found & \\
\hline Abbott & $\begin{array}{l}\text { Surbex - T } \\
\text { ViDaylin-M }\end{array}$ & $\begin{array}{c}0.15 \\
0.05 / 0.6 \mathrm{ml}\end{array}$ & $\begin{array}{c}0.130 \pm 0.004 \\
0.0412 \pm 0.0003\end{array}$ & Less recovery \\
\hline Bayer & Multibay & 0.1 & $0.96 \pm 0.003$ & Good recovery \\
\hline Boehringer-Knoll & Mittavin & 0.15 & $0.144 \pm 0.006$ & Good recovery \\
\hline Cyanamid & $\begin{array}{l}\text { Stresscaps } \\
\text { Vi-magna }\end{array}$ & $\begin{array}{c}0.15 \\
0.05 / 5 \mathrm{ml}\end{array}$ & $\begin{array}{c}0.14 \pm 0.02 \\
0.0367 \pm 0.0005\end{array}$ & Good recovery \\
\hline East India & Sorvicin & 0.5 & $0.453 \pm 0.007$ & Good recovery \\
\hline Glindia & Cobadex Forte & 0.15 & $0.150 \pm 0.004$ & Good recovery \\
\hline IDPL & $\begin{array}{l}\text { Hexavit } \\
\text { Sukcee }\end{array}$ & $\begin{array}{c}0.05 \\
0.5 \\
\end{array}$ & $\begin{array}{l}0.0471 \pm 0.0004 \\
0.4863 \pm 0.0000\end{array}$ & Good recovery \\
\hline Manners & Dropovit & $0.04 / 0.6 \mathrm{ml}$ & $0.0399 \pm 0.0003$ & Good recovery \\
\hline Merck & Polybion & 0.15 & $0.129 \pm 0.003$ & Less recovery \\
\hline Parke - Davis & Paladac & $0.0625 / 5 \mathrm{ml}$ & $0.0436 \pm 0.0004$ & Less recovery \\
\hline Pharmed & $\begin{array}{l}\text { Citravite } \\
\text { Hycibex }\end{array}$ & $\begin{array}{c}0.5 \\
0.075\end{array}$ & $\begin{array}{l}0.485 \pm 0.005 \\
0.036 \pm 0.001\end{array}$ & Good recovery \\
\hline Raptakos & Hovite & $0.08 / 5 \mathrm{ml}$ & $0.071 \pm 0.003$ & Less recovery \\
\hline Sarabhai & Limcee & 0.5 & $0.4213 \pm 0.0000$ & Less recovery \\
\hline U.S. Vitamin & Vi-Syneral & $0.04 / 0.6 \mathrm{ml}$ & $0.0361 \pm 0.0004$ & Good recovery \\
\hline
\end{tabular}

\section{CONCLUSION}

Based on Polarographic studies of ascorbic acid it is concluded Ascorbic acid (vitamin C) is easily oxidized to dehydroascorbic acid electrochemically at the surface of the dropping mercury electrode. The oxidation takes place at rather positive potentials. Oxalic acid is the extracting substance for vitamin $\mathrm{C}$ which does not interfere with the anodic wave and which do not affect the vitamin. Defined anodic diffusion current waves are obtained if the potential range of polarograph is $0-300 \mathrm{mV}$. Ascorbic acid present in various types of medicinal samples can be determined effectively with high degree of precision by measuring the anodic waves that correspond to the oxidation of measuring the anodic waves that correspond to the oxidation of enediol system by internal standard addition method. The number of electrons taking part in the reversible reaction is found to be 2 . 


\section{REFERENCES}

[1] I. Romieu, S. Monge, R. Aguilar et al., "Antioxidant supplementation and lung functions among children with asthma exposed to high levels of air pollutants," Am J Respir Crit Care Med., vol. 166, no. 5, pp. 703-709, 1 Sep. 2002.

[2] J. Guz, T. Dziaman, and A. Szpila, "Do antioxidant vitamins influence carcinogenesis?” Postepy Hig Med Dosw, vol. 61, pp. 185-198, 2007.

[3] A. Ardekani and S. Ardekani, "Effect of vitamin C on blood glucose, serum lipids \& serum insulin in type 2 diabetes patients," Indian J Med Res., vol. 126, no. 5, pp. 471-474, Nov 2007.

[4] H. Lento, C. Daugherty, and A. Denton, "Ascorbic acid measurement, polarographic determination of total ascorbic acid in foods," J. Agric. Food Chem., vol. 11, no. 1, pp. 22-26, 1963.

[5] I. Kruze, "Polarographic determination of ascorbic acid, folic acid and riboflavin," Formatsiya, vol. 18, no. 4, pp. 59-63, 1969.

[6] B. Paolo, "The polarographic determination of ascorbic acid," Boll. Chim. Unione Ital. Lab. Prov., Parte Sci., vol. 6, no. 2, pp. 143-152, 1980.

[7] U. Gerhardt and R. Windmueller, "Polarography in the determination of ascorbic acid in seasonings," Fleischwirtschaft, vol. 61, no. 9, pp. 1389-1392, 1981.

[8] J. Carvalho and B. Railton, "An enzymic and polarographic estimation of vitamin C using ascorbate oxidase," Cienc. Cult., vol. 34 , no. 11, 1482-1484, 1982.

[9] O. Lau, S. Luk, and Y. Cheung, "Simultaneous determination of ascorbic acid, caffeine and paracetamol in drug formulations by differential - pulse voltammetry using a glassy carbon electrode," Analyst, vol. 114, pp. 1047-1051, 1989.

[10] F. Belal, "Simultaneous polarographic determination of ascorbic acid and dipyrone in pharmaceutical preparations," Electroanalysis, vol. 4, no. 5, pp. 589-593, May 1992.

[11] G. Lu, Y. Wang, L. Yao, and S. Hu, "Determination of ascorbic acid in fruits and vegetables by stripping voltammetry on a glassy carbon electrode," Food Chemistry, vol. 51, issue 2, pp. 237-239, 1994.

[12] F. Sahbaz and G. Somer, "Determination of ascorbic acid in fruit and vegetables using normal polarography," Food Chemistry, vol. 44, issue 2, pp. 141-146, 1992.
[13] B. Gina, M. Mirjana, and O. Dario, "Voltammetric determination of stability constants of lead complexes with vitamin C," Croatica Chemica Acta, vol. 79, no. 1, pp. 77-83, 2006.

[14] A. Behfar, N. Sadeghi, B. Jannat, and M. Oveisi, "Determination of L-Ascorbic acid in plasma by voltammetric method," Iran J Pharm Res., vol. 9, no. 2, pp. 123-128, 2010.

[15] J. Rodrigues, I. Valente, L. Gonçalves, J. Pacheco, and A. Barros, "Polarographic determination of vitamin C after derivatization with o-phenylenediamine," Collection of Czechoslovak Chemical Communications, vol. 75, pp. 731, December 2013.

[16] C. Masram and R. Jugade, "Polarographic studies of ascorbic acid and estimation in pharmaceutical formulations and fruit juices," Int. J. Pharm. Sci. Rev. Res., vol. 22, no. 2, pp. 285-287, Sep.-Oct. 2013.

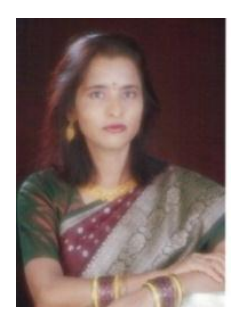

Swaroopa Rani N. Gupta was born on February 28, 1965 in Nagpur, Maharashtra, India. She got her S.S.C. in Somalwar High School, Khamla, Nagpur, Maharashtra, India, maths, science, social science in 1981; H.S.S.C. in Hislop College, Nagpur, Maharashtra, India in maths \& statistics, chemistry, biology in 1983; B.Sc. in Shivaji Science College, Nagpur, Maharashtra, India in chemistry, zoology, microbiology in 1986; M.Sc. in Post Graduate Teaching Department of Chemistry, Nagpur, Maharashtra, India in chemistry specialization: analytical chemistry in 1988 M.Phil. in Post Graduate Teaching Department of Chemistry, Nagpur, Maharashtra, India in coordination chemistry, polymer chemistry in 1989; Ph.D. in Post Graduate Teaching Department of Chemistry, Nagpur, Maharashtra, India in chemistry in 1993.

She was now an associate professor in the Department of Chemistry, Brijlal Biyani Science College, Amravati, Maharashtra, India

Her research interests are in the field of chemistry especially analytical chemistry, environmental science and recent technologies connected to different field. She wants to explore world through great research interest in all aspect of world problem. 